\title{
Pemanfaatan Lemna minor L. dan Hydrilla verticillata (L.f.) Royle untuk Memperbaiki Kualitas Air Limbah Laundry
}

\author{
Maya Safitri ${ }^{1}$, Mukarlina ${ }^{1}$, Tri Rima Setyawati ${ }^{1}$ \\ ${ }^{1}$ Program Studi Biologi, Fakultas MIPA, Universitas Tanjungpura, Jl. Prof. Dr. H. Hadari Nawawi, Pontianak, \\ Email korespondensi : mayasafitri008@gmail.com
}

\begin{abstract}
Lemna minor and Hydrilla verticillata are types of water plants that have the potential to have the ability to process and improve the quality of polluted water. The purpose of this study is to determine the ability of Lemna minor and Hydrilla verticillata in improving the quality of laundry wastewater. The study used a completely randomized design (CRD) method with six treatments and three replications. The study was carried out on test media in the form of 5 liters of laundry wastewater with L. minor (L) $100 \mathrm{~g}$, H. verticillata $(\mathrm{H}) 100$ $\mathrm{g}$, and combination treatment of both plants $(\mathrm{L} 1 \mathrm{H} 1, \mathrm{~L} 1 \mathrm{H} 2, \mathrm{~L} 2 \mathrm{H} 1)$ in weight L1H1 $(50 \mathrm{~g}: 50 \mathrm{~g}), \mathrm{L} 1 \mathrm{H} 2(33 \mathrm{~g}$ : $67 \mathrm{~g}$ ) and L2H1 (67 g : $33 \mathrm{~g}$ ) for 14 days after acclimation for one week. The combination of $L$. minor and $H$. verticillata with a ratio of 1:2 was able to reduce the highest Total Suspended Solid (TSS) and Total Dissolved Solid (TDS) of laundry wastewater with a decrease of $52.87 \%$ and $4.02 \%$ and increase dissolved oxygen (DO) of $7.13 \mathrm{mg} / \mathrm{L}$. The highest decrease in chlorine occurred in $L$. minor and $H$. verticillata treatments with a ratio of $1: 1$ of $0.110 \mathrm{mg} / \mathrm{L}$. All treatments of L. minor and H. verticillata both singly and in combination have not been able to reduce the phosphate content in laundry wastewater on day 14 of treatment.
\end{abstract}

Keywords : Phytoremediation, Lemna minor, Hydrilla verticillata and laundry wastewater

\section{PENDAHULUAN}

Usaha laundry yang bersifat rumahan umumnya membuang air limbah sisa cucian langsung ke badan air tanpa proses pengolahan terlebih dahulu, sehingga menyebabkan terjadinya pencemaran lingkungan (Wardhana, 2013). Berdasarkan data yang didapat dari Badan Lingkungan Hidup (BLH) Kota Pontianak, tahun 2017. terdapat hanya 7 dari 48 usaha laundry yang melakukan pengolahan limbah atau memiliki Instalasi Pengolahan Air Limbah (IPAL). Kondisi tersebut dapat diatasi apabila dilakukan pengolahan dengan metode fitoremediasi. Fitoremediasi merupakan metode pengolahan air limbah dengan memanfaatkan tanaman air.

Hasil penelitian Sudiro \& Agnes (2013) yang memanfaatkan $L$. minor dan $H$. verticillata dalam mereduksi Chemical Oxygen Demand (COD) pada air limbah industri tahu berhasil menurunkan COD sebesar 97,62\%. Hasil penelitian Sumiyati et al., (2009) yang menggunakan $H$. verticillata juga berhasil menurunkan kadar logam $(\mathrm{Cu})$ pada air limbah elektroplating sebesar $84 \%$ dan hasil penelitian Tati (2017) juga menyatakan bahwa $H$. verticillata memiliki kemampuan mengurangi TSS sebesar 80,63\% pada air limbah industri tahu. $L$. minor dan $H$. verticillata merupakan tanaman air yang diduga berpotensi memiliki kemampuan memperbaiki kualitas air limbah. Oleh karena itu, perlu dilakukan penelitian fitoremediasi dengan menggunakan $L$. minor dan $H$. verticillata pada air limbah laundry.

\section{BAHAN DAN METODE \\ Bahan}

Bahan-bahan yang digunakan dalam penelitian ini adalah air limbah laundry, L. minor, H. verticillata, akuades, mangan sulfat $\left(\mathrm{MnSO}_{4}\right)$, asam sulfat $\left(\mathrm{H}_{2} \mathrm{SO}_{4}\right)$, kalium hidroksida $(\mathrm{KOH})$, kalium iodida (KI), dan natrium tiosulfat $\left(\mathrm{Na}_{2} \mathrm{~S}_{2} \mathrm{O}_{3}\right)$.

\section{Waktu dan Tempat Penelitian}

Penelitian dilaksanakan pada bulan Januari - Maret 2018 di Rumah Kasa dan Laboratorium Jurusan Biologi Fakultas Matematika dan Ilmu Pengetahuan Alam Universitas Tanjungpura Pontianak. Analisa klorin dan fosfat di Laboratorium Balai Riset dan Standardisasi Industri (BARISTAND) Pontianak.

\section{Rancangan Penelitian}

Penelitian menggunakan rancangan acak lengkap (RAL) terdiri dari 6 perlakuan yakni L. minor (L) 100 gram, $H$. verticillata 100 gram $(H)$ gram dan perlakuan kombinasi dari kedua tanaman (L1H1, L1H2, L2H1) dengan berat secara berurutan L1H1 (50 g : $50 \mathrm{~g}$ ), L1H2 (33 g : $67 \mathrm{~g})$ dan L2H1 (67 g : 33 g). Masing - masing perlakuan terdiri dari 3 ulangan sehingga diperoleh 18 unit percobaan. 


\section{Prosedur Kerja}

Persiapan Media Uji dan Tumbuhan Uji

Air limbah laundry diambil dari buangan pertama dan diencerkan $75 \%$. Air limbah yang telah diencerkan ditempatkan dalam 18 bak perlakuan dengan volume 5 liter. $L$. minor dan $H$. verticillata diambil dari lingkungan alaminya dan diaklimasi selama 1 minggu. Setiap bak berisi $100 \mathrm{~g}$ tanaman dengan perbandingan (L 100 g, H 100 g, L1H1 50 g L dan $50 \mathrm{~g} \mathrm{H}, \mathrm{L} 1 \mathrm{H} 233 \mathrm{~g} \mathrm{~L}$ dan $67 \mathrm{~g} \mathrm{H}, \mathrm{L} 2 \mathrm{H} 167 \mathrm{~g}$ $\mathrm{L}$ dan $33 \mathrm{~g} \mathrm{H})$.

\section{Derajat keasaman $(\mathrm{pH})$}

Derajat keasaman (pH) media uji diukur menggunakan $\mathrm{pH}$ meter dengan cara ujung $\mathrm{pH}$ meter dimasukkan ke dalam media uji dan tombol ditekan. Setelah angka konstan, angka dicatat.

\section{Suhu $\left({ }^{0} \mathrm{C}\right)$}

Suhu udara rumah kasa dan media uji diukur menggunakan termometer setiap hari selama 14 hari perlakuan.

\section{Total Dissolved Solid (TDS)}

Total Dissolved Solid (TDS) dihitung menggunakan metode gravimetri. Beaker dibersihkan dengan akuades dan dioven, selama 1 jam pada suhu $105^{\circ} \mathrm{C}$. Dimasukkan ke desikator 15 menit, ditimbang dan dicatat hasilnya, dilakukan duplo (A). Disaring air sampel $100 \mathrm{ml}$ dengan kertas saring. Dimasukkan air sampel $50 \mathrm{ml}$ ke dalam gelas beaker, lalu oven hingga kering. Dimasukkan dalam desikator 15 menit, lalu ditimbang, dicatat hasilnya, lakukan duplo (B) dan hasil yang diperoleh dihitung dengan rumus:

$\operatorname{TDS}(\mathrm{mg} / \mathrm{L})=\frac{(\mathrm{A}-\mathrm{B}) \times 1000}{\text { volume sampel }}$

\section{Total Suspended Solid (TSS)}

Total Suspended Solid (TSS) dihitung menggunakan metode gravimetri. Kertas saring dibersihkan dengan akuades. Kertas saring dioven selama 1 jam pada suhu $105^{\circ} \mathrm{C}$, masukkan ke desikator selama 15 menit, ditimbang, lakukan duplo (A). Sampel $100 \mathrm{ml}$ disaring, masukkan kertas saring ke dalam oven selama 1 jam pada suhu $105^{\circ} \mathrm{C}$. Masukkan ke desikator 15 menit, timbang, lakukan duplo (B). Hasil yang diperoleh dihitung dengan rumus:

$\operatorname{TSS}(\mathrm{mg} / \mathrm{L})=\frac{(\mathrm{A}-\mathrm{B}) \times 1000}{\text { volume sampel }}$

Dissolved Oksigen (DO)

Sampel air $125 \mathrm{ml}$. Ditambahkan $1 \mathrm{ml} \mathrm{MnSO}_{4}$ dan $1 \mathrm{ml} \mathrm{KOH}-\mathrm{KI}$, lalu kocok dan diamkan hingga terbentuk endapan putih/coklat. Ditambahkan $1 \mathrm{ml}$ $\mathrm{H}_{2} \mathrm{SO}_{4}$ kocok dan diamkan 10 menit hingga larutan sampel berwarna. Diambil sebanyak $100 \mathrm{ml}$ ke erlenmeyer, ditetesi $\mathrm{Na}_{2} \mathrm{~S}_{2} \mathrm{O}_{3}, 0,0125 \mathrm{~N}$, hingga sampel berwarna kuning pucat. Ditambahkan 5 tetes amilum, sampel berubah warna biru, lalu dititrasi dengan $\mathrm{Na}_{2} \mathrm{~S}_{2} \mathrm{O}_{3}, 0,0125 \mathrm{~N}$. Sampel menjadi bening, dihitung volume $\mathrm{Na}_{2} \mathrm{~S}_{2} \mathrm{O}_{3}$ yang terpakai (=nilai DO akhir) dengan rumus:

$\mathrm{DO}(\mathrm{mg} / \mathrm{L})=\mathrm{Vt} \times \mathrm{N}$ X8000)/ Vs)

Keterangan:

$\mathrm{Vt}=$ Volume $\mathrm{Na}_{2} \mathrm{~S}_{2} \mathrm{O}_{3}(\mathrm{ml})$

$\mathrm{N}=$ Normalitas $\mathrm{Na}_{2} \mathrm{~S}_{2} \mathrm{O}_{3}(\mathrm{~N})$

Vs $=$ Volume sampel (ml)

Fosfat

Analisis fosfat menggunakan metode uji SNI 066989.31 - 2005. Sampel air ditimbang, ditambahkan $\mathrm{HNO}_{3}$ (1:3). Campuran dipanaskan, setelah mendidih selama 20 menit, diencerkan dengan akuades hingga volume tertentu, digojok hingga homogen. Sebanyak $1 \mathrm{ml}$ campuran homogen ditambahkan $3 \mathrm{ml}$ pereaksi vanadat molibdat, kemudian divortek dan diamkan selama 20 menit. Campuran diencerkan dengan akuades hingga volume akhir $5 \mathrm{ml}$ dan diukur absorbansinya pada panjang $420 \mathrm{~nm}$.

\section{Klorin}

Analisis klorin dilakukan di Laboratorium Balai Riset dan Standardisasi Industri (BARISTAND) Pontianak dengan HACH Method 8021.

\section{Perhitungan Efektifitas}

Perhitungan efektifitas penurunan setiap parameter dihitung dengan rumus (Dewi dan Masithoh, 2013)

Efektifitas $=\frac{A-B}{A} \times 100 \%$

Keterangan: $\mathrm{A}=$ Pengukuran awal $\mathrm{B}=$ Pengukuran akhir

Berat Basah dan Berat Kering L. minor dan H. verticillata

a. Berat Basah (BB)

Penimbangan berat basah dilakukan sebelum dan sesudah perlakuan, dengan menimbang berat segar tanaman yang telah dibersihkan dan ditiriskan terlebih dahulu.

b. Berat Kering (BK)

Penimbangan berat kering dilakukan pada akhir perlakuan setelah tanaman dikeringkan dalam oven pada suhu $60^{\circ} \mathrm{C}$ hingga mencapai berat yang konstan. 


\section{Analisis Data}

Data hasil pengukuran Dissolved oxygen (DO), Total Suspended Solid (TSS), Total Dissolved Solid (TDS), klorin, fosfat, berat basah (BB) dan berat kering (BK) dianalisis secara statistik menggunakan Analisis Varian (ANOVA) SPSS 18. Jika terdapat perbedaan nyata dilakukan uji lanjut Duncan pada selang kepercayaan 95\% (Hanafiah, 2004).

\section{HASIL DAN PEMBAHASAN \\ Hasil \\ Kualitas Fisika dan Kimia Air Limbah Laundry Sebelum Perlakuan}

Pengujian kualitas awal air limbah laundry menunjukkan bahwa parameter klorin dan fosfat berada di atas baku mutu air limbah berdasarkan Peraturan Pemerintah Nomor 82 Tahun 2001. Hasil pengujian kualitas air limbah laundry sebagai media uji pada penelitian disajikan pada Tabel 1 .

Air limbah laundry setelah diolah dengan metode fitoremediasi menggunakan $L$. minor dan $H$. verticillata menunjukkan penurunan Total Suspended Solid (TSS) dan Total Dissolved Solid (TDS). Hasil uji Anova menunjukkan bahwa perlakuan dengan menggunakan $L$. minor dan $H$. verticillata berpengaruh nyata terhadap penurunan
TSS air limbah laundry $(\mathrm{F}=501,60, p=0,000$; Anova).

Tabel. 1 Kualitas Fisika dan Kimia Air Limbah Laundry Sebelum Perlakuan

\begin{tabular}{cccc}
\hline $\begin{array}{c}\text { Parameter } \\
\text { Uji }\end{array}$ & Satuan & $\begin{array}{c}\text { Hasil } \\
\text { Uji }\end{array}$ & $\begin{array}{c}\text { Baku } \\
\text { Mutu }\end{array}$ \\
\hline DO & $\mathrm{mg} / \mathrm{L}$ & 0 & 6 \\
TSS & $\mathrm{mg} / \mathrm{L}$ & 57,3 & 400 \\
TDS & $\mathrm{mg} / \mathrm{L}$ & 796 & 2000 \\
Klorin & $\mathrm{mg} / \mathrm{L}$ & 0,230 & 0,03 \\
Fosfat & $\mathrm{mg} / \mathrm{L}$ & 0,861 & 0,2 \\
Suhu & ${ }^{0} \mathrm{C}$ & 25 & - \\
pH & - & 6,8 & $6-9$ \\
\hline
\end{tabular}

Keterangan : Hasil uji Laboratorium Balai Riset dan Standardisasi Industri (BARISTAND) Pontianak.

Hasil pengukuran TSS sebelum perlakuan (0 hari) $57,3 \mathrm{mg} / \mathrm{L}$ dan setelah perlakuan selama 14 hari berkisar antara 27-30 mg/L (Tabel. 2). Semua perlakuan berbeda nyata terhadap kontrol. Perlakuan kombinasi L1H1 dan L1H2 berbeda nyata terhadap perlakuan $L$. minor $(\mathrm{L})$ tetapi tidak berbeda nyata terhadap perlakuan $H$. verticillata $(\mathrm{H})$ dan perlakuan kombinasi L2H1. Perlakuan kombinasi L1H2 mengalami penurunan TSS tertinggi dengan persentase penurunan $52,87 \%$ (Tabel. 2).

Tabel. 2 Rata-rata Nilai TSS dan TDS Air Limbah Laundry Setelah Perlakuan

\begin{tabular}{ccccc}
\hline Perlakuan & TSS (mg/L) & $\begin{array}{c}\text { Persentase } \\
\text { Penurunan TSS } \\
(\mathbf{\%})\end{array}$ & TDS (mg/L) & $\begin{array}{c}\text { Persentase } \\
\text { Penurunan TDS } \\
(\boldsymbol{\%})\end{array}$ \\
\hline Kontrol & $57,00^{\mathrm{c}} \pm 1,00$ & 0,52 & $796,00^{\mathrm{e}} \pm 3,05$ & 0 \\
L & $30,00^{\mathrm{b}} \pm 1,00$ & 47,64 & $779,33^{\mathrm{d}} \pm 1,15$ & 2,09 \\
H & $28,33^{\mathrm{ab}} \pm 0,57$ & 50,55 & $775,33^{\mathrm{cd}} \pm 4,16$ & 2,59 \\
L1H1 & $27,00^{\mathrm{a}} \pm 1,00$ & $\mathbf{5 2 , 8 7}$ & $768,67^{\mathrm{ab}} \pm 1,15$ & 3,43 \\
L1H2 & $27,33^{\mathrm{a}} \pm 0,57$ & $\mathbf{5 2 , 3 0}$ & $764,00^{\mathrm{a}} \pm 3,46$ & $\mathbf{4 , 0 2}$ \\
L2H1 & $28,33^{\mathrm{a}} \pm 1,15$ & 50,55 & $772,00^{\mathrm{b}} \pm 2,00$ & 3,01 \\
\hline
\end{tabular}

Keterangan : Angka-angka pada yang sama dan diikuti oleh huruf kecil yang berbeda menunjukkan pengaruh yang nyata pada uji Duncan, taraf uji 95\%. L (L. minor), H (H. verticillata).

Total Dissolved Solid (TDS) air limbah laundry setelah perlakuan menggunakan L. minor dan $H$. verticillata mengalami penurunan dan berpengaruh nyata terhadap TDS $(\mathrm{F}=51,812, p=0,000$; Anova). Hasil pengukuran TDS sebelum perlakuan (0 hari) yaitu $796 \mathrm{mg} / \mathrm{L}$ dan setelah perlakuan selama 14 hari berkisar antara $764-779,33 \mathrm{mg} / \mathrm{L}$. Semua perlakuan berbeda nyata terhadap kontrol. Perlakuan kombinasi L1H2 tidak berbeda nyata terhadap perlakuan kombinasi LIH1 tetapi berbeda nyata terhadap perlakuan $L$. minor (L), $H$. verticillata $(\mathrm{H})$, dan perlakuan kombinasi $\mathrm{L} 2 \mathrm{H} 1$. Perlakuan kombinasi LIH2 mengalami penurunan TDS tertinggi dengan persentase 4,02\% (Tabel. 2).

Hasil analisa Anova menunjukkan bahwa perlakuan dengan menggunakan $L$. minor dan $H$. verticillata berpengaruh nyata terhadap Dissolved Oxygen (DO) air limbah laundry ( $\mathrm{F}=6,191, p=0,005$; Anova). Hasil pengukuran DO sebelum perlakuan (0 hari) sebesar $0 \mathrm{mg} / \mathrm{L}$ dan setelah perlakuan 
selama 14 hari berkisar antara 5,06- 7,13 mg/L (Tabel. 3).

Tabel. 3 Rata-rata Nilai Dissolved Oksigen (DO) Air Limbah Laundry Setelah Perlakuan

\begin{tabular}{cc}
\hline Perlakuan & DO $(\mathbf{m g} / \mathbf{L})$ \\
\hline Kontrol & $5,03^{\mathrm{a}} \pm 0,57$ \\
L & $5,93^{\mathrm{ab}} \pm 0,20$ \\
H & $5,06^{\mathrm{a}} \pm 0,49$ \\
L1H1 & $6,50^{\mathrm{b}} \pm 1,21$ \\
L1H2 & $7,13^{\mathrm{b}} \pm 0,28$ \\
L2H1 & $7,00^{\mathrm{b}} \pm 0,79$
\end{tabular}

Keterangan : Angka-angka pada yang sama dan diikuti oleh huruf kecil yang berbeda menunjukkan pengaruh yang nyata pada uji Duncan, taraf uji 95\%. L (L. minor), $\mathrm{H}$ (H. verticillata).

Nilai derajat keasaman $(\mathrm{pH})$ air limbah laundry sebelum perlakuan adalah 6,8 dan setelah perlakuan berkisar antara 7,1 - 7,5 (Tabel. 4).

Tabel. 4 Rata-rata Nilai Derajat Keasaman (pH) Air Limbah Laundry Sebelum dan Setelah Perlakuan

\begin{tabular}{ccc}
\hline Perlakuan & Sebelum & Setelah \\
\hline Kontrol & 6,8 & 7,1 \\
L & 6,8 & 7,3 \\
H & 6,8 & 7,4 \\
L1H1 & 6,8 & 7,4 \\
L1H2 & 6,8 & 7,5 \\
L2H1 & 6,8 & 7,4 \\
\hline
\end{tabular}

Keterangan : K (Kontrol), L (Lemna minor), H (Hydrilla verticillata)
Hasil uji klorin air limbah laundry sebelum perlakuan (0 hari) adalah $0,230 \mathrm{mg} / \mathrm{L}$ dan setelah perlakuan selama 14 hari berkisar antara $0,11-0,25$ mg/L (Tabel. 5). Hasil analisa Anova menunjukkan terdapat perbedaan nyata penurunan klorin air limbah laundry $(\mathrm{F}=9,613, p=0,001$; Anova $)$. Perlakuan L1H1 berbeda nyata dengan perlakuan kombinasi L1H2, dan kombinasi L2H1 tetapi tidak berbeda nyata dengan perlakuan kontrol $(\mathrm{K}), L$. minor (L) dan $H$. verticillata $(\mathrm{H})$.

Tabel. 5 Rata-rata Nilai Klorin dan Nilai Fosfat Air Limbah Laundry Setelah Perlakuan

\begin{tabular}{ccc}
\hline Perlakuan & $\begin{array}{c}\text { Fosfat } \\
(\mathbf{m g} / \mathbf{L})\end{array}$ & $\begin{array}{c}\text { Klorin } \\
(\mathbf{m g} / \mathbf{L})\end{array}$ \\
\hline Kontrol & $2,07^{\mathrm{a}} \pm 0,08$ & $0,04^{\mathrm{a}} \pm 0,03$ \\
L & $14,83^{\mathrm{b}} \pm 0,75$ & $0,14^{\mathrm{b}} \pm 0,04$ \\
H & $13,76^{\mathrm{b}} \pm 1,35$ & $0,16^{\mathrm{bc}} \pm 0,06$ \\
L1H1 & $19,73^{\mathrm{bc}} \pm 4,02$ & $0,11^{\mathrm{ab}} \pm 0,03$ \\
L1H2 & $24,96^{\mathrm{cd}} \pm 5,71$ & $0,25^{\mathrm{c}} \pm 0,05$ \\
L2H1 & $26,20^{\mathrm{d}} \pm 4,52$ & $0,25^{\mathrm{c}} \pm 0,03$ \\
\hline Keterangan : & \multicolumn{2}{c}{ Angka-angka pada yang sama dan diikuti } \\
& oleh huruf kecil yang berbeda \\
& menunjukkan pengaruh yang nyata pada \\
& uji Duncan, taraf uji 95\%. L (L. minor), \\
& H $(H$. verticillata $)$.
\end{tabular}

Hasil analisa Anova menunjukkan perlakuan dengan menggunakan $L$. minor dan $H$. verticillata pada air limbah laundry berpengaruh nyata pada fosfat ( $\mathrm{F}=19,755, p=0,000$; Anova). Fosfat setelah perlakuan selama 14 hari mengalami peningkatan berkisar antara 13,76 - 26,20 mg/L. Fosfat terendah setelah perlakuan terdapat pada perlakuan $H$. verticillata $(\mathrm{H})$ yaitu $13,76 \mathrm{mg} / \mathrm{L}$ (Tabel. 5). Perlakuan kombinasi L1H1 tidak berbeda nyata dengan perlakuan L. minor $(\mathrm{L}), H$. verticillata $(\mathrm{H})$, dan kombinasi $\mathrm{L} 1 \mathrm{H} 2$ tetapi berbeda nyata dengan kontrol dan perlakuan kombinasi L2H1.

Tabel. 6 Persentase Penurunan Berat Basah (BB) Sebelum dan Sesudah Pencucian serta Berat Kering (BK) L. minor dan $H$. verticillata pada tiap Perlakuan

\begin{tabular}{cccc}
\hline Perlakuan & $\begin{array}{c}\text { Berat Basah Sebelum } \\
\text { Pencucian (gr) }\end{array}$ & $\begin{array}{c}\text { Berat Basah Setelah } \\
\text { Pencucian (gr) }\end{array}$ & Berat Kering (gr) \\
\hline Berat awal & 100 & 100 & - \\
L & $36,44^{\mathrm{ab}} \pm 0,92$ & $36,05^{5^{\mathrm{b}} \pm 0,91}$ & $3,45^{\mathrm{b}} \pm 0,39$ \\
H & $35,30^{\mathrm{ab}} \pm 1,88$ & $34,79^{\mathrm{a}^{\mathrm{b}} \pm 1,94}$ & $3,31^{\mathrm{b}} \pm 0,09$ \\
L1H1 & $36,35^{\mathrm{a}} \pm 1,71$ & $36,02^{\mathrm{a}^{\mathrm{b}} \pm 1,81}$ & $3,39^{\mathrm{b}} \pm 0,52$ \\
L1H2 & $33,94^{\mathrm{a}} \pm 1,19$ & $33,79^{\mathrm{a}} \pm 0,98$ & $2,59^{\mathrm{a}^{\mathrm{a}} \pm 0,14}$ \\
L2H1 & $37,42^{\mathrm{b}} \pm 1,32$ & $37,22^{\mathrm{b}} \pm 1,44$ & $3,58^{\mathrm{b}} \pm 0,25$ \\
\hline
\end{tabular}

Keterangan : Angka-angka pada yang sama dan diikuti oleh huruf kecil yang berbeda menunjukkan pengaruh yang nyata pada uji Duncan, taraf uji 95\%. L (L. minor), H (H. verticillata). 


\section{Pembahasan}

Air limbah laundry sebelum perlakuan mengandung Total Suspended Solid (TSS) dan Total Dissolved Solid (TDS) cukup tinggi. Hasil pengukuran TSS dan TDS mengalami penurunan setelah perlakuan selama 14 hari dengan menggunakan $L$. minor dan $H$. verticillata. Pengukuran TSS air limbah laundry sebelum perlakuan (hari ke-0) sebesar $57,3 \mathrm{mg} / \mathrm{L}$ dan TDS sebesar $796 \mathrm{mg} / \mathrm{L}$ (Tabel. 1) setelah perlakuan selama 14 hari TSS menurun berkisar antara 27 - $30 \mathrm{mg} / \mathrm{L}$ dengan rentang persentase penurunan $47,64 \%$ - 52,87\% dan TDS berkisar antara 764 - 779,33 mg/L dengan rentang persentase penurunan 2,09\% - 4,02\% (Tabel. 2).

Kadar TSS dan TDS pada semua perlakuan telah memenuhi standar baku mutu. Menurut Peraturan Pemerintah Republik Indonesia nomor 82 tahun 2001 Tentang Pengelolaan Kualitas Air dan Pengendalian Pencemaran Air, baku mutu TSS air limbah dari kegiatan domestik, termasuk usaha laundry sebesar $400 \mathrm{mg} / \mathrm{L}$ dan baku mutu TDS sebesar $2000 \mathrm{mg} / \mathrm{L}$ (Tabel. 1). Persentase penurunan TSS dan TDS tertinggi setelah perlakuan selama 14 hari terdapat pada perlakuan kombinasi L1H2 dengan penurunan TSS sebesar $52,87 \%$ dan penurunan TDS sebesar 4,02\% (Tabel. 2).

Kondisi ini mengindikasikan bahwa perlakuan kombinasi L1H2 lebih efektif menurunkan TSS dan TDS dibanding perlakuan lain. Kondisi ini diduga karena sifat tanaman uji yang digunakan berbeda, yaitu L. minor mengapung (floating aquatic plant) dan $H$. verticillata tenggelam (the deep aquatic plant). Menurut Reddy \& De Busk (1985) tanaman air yang bersifat mengapung lebih sering digunakan dalam fitoremediasi dibanding tanaman air yang bersifat tenggelam dikarenakan tingkat pertumbuhannya yang tinggi. Tanaman air $H$. verticillata yang bersifat tenggelam juga diduga memiliki peran yang penting bila dikombinasikan dengan $L$. minor yang bersifat mengapung. Hal ini didukung dari hasil penelitian Sudiro \& Agnes (2013) yang mereduksi Chemical Oxygen Demand (COD) air limbah industri tahu sebesar 97,62\% dengan memanfaatkan L. minor dan H. verticillata. Hal ini juga didukung dari hasil penelitian Tati (2017) yang menyatakan bahwa $H$. verticillata memiliki kemampuan mengurangi TSS sebesar 80,63\% pada air limbah industri tahu.

Kemampuan perlakuan kombinasi L1H2 menurunkan TSS dan TDS dengan variasi berat $L$. minor 33 gram dan $H$. verticillata 67 gram, menunjukkan adanya pengaruh berat tanaman dan morfologi tanaman dalam penyerapan TSS dan TDS. Akar memegang peran penting dalam menyerap TSS dan TDS dalam proses fitoremediasi. Menurut Sudiro \& Agnes (2013) $H$. verticillata selain memanfaatkan akar, juga memanfaatkan daun dan batangnya yang ikut terendam dalam air limbah untuk menyerap TSS dan TDS, sementara L. minor hanya memanfaatkan akarnya.

Hal ini diduga menyebabkan tanaman $H$. verticillata mampu menyerap TSS dan TDS lebih banyak sehingga persentase penurunannya juga menjadi lebih besar dibanding L. minor. Kondisi ini sesuai dengan hasil penelitian pada Tabel 4.2 yang menunjukkan perlakuan $H$. verticillata $(\mathrm{H})$ dan kombinasi (L1H2) lebih banyak menyerap TSS dan TDS dibanding perlakuan lain.

Penurunan TSS dan TDS juga diduga dipengaruhi lamanya waktu kontak tanaman pada air limbah laundry. Penelitian Endro et al. (2010) yang memanfaatkan $L$. minor dan $H$. verticillata untuk meremediasi limbah cair domestik selama 20 hari dan menunjukkan adanya penurunan TSS dengan persentase tertinggi terjadi pada hari ke 20 sebesar $72,44 \%$ dibanding hari ke-5, hari ke-10 dan hari ke15. Hal ini mengindikasikan adanya keterkaitan antara lama waktu kontak tanaman dengan penurunan TSS dan TDS.

Kadar Dissolved oxygen (DO) berdasarkan hasil pengukuran (Tabel. 3) berada di atas baku mutu minimum sesuai Peraturan Pemerintah Republik Indonesia Nomor 82 Tahun 2001 yang mengindikasikan bahwa parameter DO telah memenuhi standar baku mutu.

Menurut Kristanto (2002) oksigen yang terdapat pada air limbah dihasilkan dari proses fotosintesis tanaman air dan proses difusi langsung dari udara yang masuk ke dalam air. Dissolved oxygen (DO) tertinggi terdapat pada semua perlakuan kombinasi (L1H1, L1H2 dan L2H1) dengan penggunaan dua tanaman L. minor dan $H$. verticillata. Meningkatnya DO diduga karena adanya suplai oksigen dari hasil proses fotosintesis kedua tanaman tersebut yang berlangsung dalam bak perlakuan yang sama sehingga DO pada perlakuan kombinasi lebih tinggi dibanding perlakuan lain (Tabel. 3).

Hasil pengukuran derajat keasaman $(\mathrm{pH})$ air limbah laundry sebelum perlakuan bersifat asam sebesar 6,8 dan setelah perlakuan mengalami kenaikan $\mathrm{pH}$ menjadi \pm 7 (netral) pada tiap perlakuan (Tabel. 4). 
Nilai tersebut menunjukkan bahwa parameter $\mathrm{pH}$ telah memenuhi standar baku mutu untuk pengelolaan dan pengendalian pencemaran air berdasarkan Peraturan Pemerintah Nomor 82 Tahun 2001 dengan rentang pH 6 -9.

Air limbah umumnya mempunyai $\mathrm{pH}$ yang asam (Hidayah \& Aditia, 2010). Hasil penelitian Agussetydevy et al. (2013) menyatakan bahwa fitoremediasi dapat meningkatkan $\mathrm{pH}$ air limbah menjadi pH netral. Penelitian Nasrullah et al. (2015) yang memanfaatkan tanaman Typha angustifolia pada proses fitoremediasi air limbah karet juga menghasilkan peningkatan $\mathrm{pH}$ menjadi netral.

Peningkatan $\mathrm{pH}$ terjadi karena proses degradasi bahan-bahan organik pada air limbah laundry, adanya $L$. minor dan $H$. verticillata menyebabkan terjadinya suplai oksigen ke dalam air limbah sehingga mempengaruhi proses degradasi bahan bahan organik menjadi lebih cepat. Saat kadar bahan organik menurun, gas $\mathrm{CO}_{2}$ yang dihasilkan dari proses penguraian zat organik juga sedikit, sehingga asam karbonat yang berasal dari pendifusian $\mathrm{CO}_{2}$ dengan air akan berkurang. Berkurangnya asam karbonat menyebabkan terjadinya peningkatan $\mathrm{pH}$. Hal ini sejalan dengan penelitian Muhajir (2013) mengenai pengolahan air limbah tahu menggunakan tanaman Typha angustifolia. Hasil penelitiannya menunjukan terjadinya peningkatan $\mathrm{pH}$. $\mathrm{pH}$ awal air limbah tahu adalah 4,5 dan pada hari ke-20 penelitian $\mathrm{pH}$ naik menjadi 6 .

Hasil pengukuran fosfat setelah perlakuan selama 14 hari menggunakan $L$. minor dan $H$. verticillata menunjukkan hasil yang lebih tinggi dibanding kontrol berkisar antara 13,76 - 26,20 mg/L (Tabel. 5). Nilai fosfat tersebut menunjukkan belum memenuhi standar baku mutu berdasarkan Peraturan Pemerintah Republik Indonesia Nomor 82 Tahun 2001 Tentang Pengelolaan Kualitas Air dan Pengendalian Pencemaran Air, yaitu 0,2 mg/L. Kondisi ini diduga disebabkan karena fosfat dalam air limbah laundry mengalami perubahan secara fluktuatif dari waktu ke waktu.

Perubahan fosfat secara fluktuatif sejalan dengan hasil penelitian Stefhany (2013) yang menggunakan eceng gondok dalam meremediasi fosfat dalam air limbah laundry. Perubahan fosfat secara fluktuatif terjadi pada berbagai waktu kontak yaitu ( 0 hari, 5 hari, 10 hari, 15 hari dan 20 hari). Penyerapan fosfat terjadi pada hari ke-5 dan hari ke-10, namun terjadi peningkatan fosfat pada hari ke-15 dan ke-20.
Penelitian Oktavia et al. (2013) yang menggunakan genjer, kangkung air dan eceng gondok dalam meremediasi fosfat dalam air limbah laundry dalam waktu perlakuan selama 8 hari hasilnya menunjukkan hanya terjadi penurunan fosfat pada hari ke 2 hingga hari ke 6 pada hari ke 8 fosfat mengalami peningkatan.

Berdasarkan hasil penelitian Stefhany (2013) dan Oktavia et al. (2013) diduga fosfat yang terkandung dalam air limbah laundry pada penelitian ini juga mengalami perubahan secara fluktuatif hanya saja tidak dilakukan pengukuran secara berkala sehingga belum dapat diketahui waktu terjadinya penurunan fosfat.

Fosfat yang tidak mengalami penurunan juga diduga karena banyaknya jenis dan kandungan unsur hara dalam air limbah laundry serta adanya kondisi kompetitif penyerapan unsur hara oleh tanaman dengan unsur hara lainnya yang terdapat pada air limbah laundry. Hasil penelitian Utami (2018) terkait fitoremediasi nitrogen dan fosfat, menyebutkan bahwa kehadiran nitrogen menyebabkan penurunan serapan fosfat oleh $L$. perpusilla. Penurunan tersebut disebabkan karena ukuran ion nitrogen lebih kecil dari ion fosfat sehingga ion nitrogen cenderung lebih dulu masuk ke dalam sel akar dibandingkan fosfat. Secara umum fosfat dan nitrogen merupakan unsur hara esensial bagi tanaman. Akan tetapi persentase unsur nitrogen yang diperlukan tanaman untuk tumbuh lebih tinggi dibandingkan persentase unsur fosfat, sehingga nitrogen terserap lebih banyak dibanding fosfat. Hal ini juga diduga terjadi pada air limbah laundry. Hasil penelitian Savitri (2007) menyebutkan bahwa air limbah laundry juga mengandung unsur nitrogen selain unsur fosfat.

Peningkatan fosfat juga diduga karena dipengaruhi berat tanaman uji yang digunakan. Pernyataan ini didukung dengan hasil penelitian Sumiyati (2009) yang menggunakan $H$. verticillata untuk meremediasi fosfat pada air limbah kerajinan perak dengan kandungan awal fosfat $4,628 \mathrm{mg} / \mathrm{L}$ dan berat $H$. verticillata yang digunakan yaitu $150 \mathrm{~g}, 200 \mathrm{~g}$ dan 250 g. Hasil menunjukkan terjadinya penurunan fosfat sejalan dengan penggunaan berat tanaman uji dengan rata-rata fosfat pada masing-masing variasi berat yaitu $150 \mathrm{~g}(2,106 \mathrm{mg} / \mathrm{L}), 200 \mathrm{~g}(1,368 \mathrm{mg} / \mathrm{L})$ dan $250 \mathrm{~g}(0,862 \mathrm{mg} / \mathrm{L}$. Berat $L$. minor dan $H$. verticillata 100 gram yang digunakan pada tiap perlakuan dalam penelitian ini masih belum berimbang untuk penyerapan fosfat dalam air limbah laundry. 
Hasil pengukuran klorin air limbah laundry sebelum perlakuan menunjukkan nilai yang tinggi, yaitu $0,230 \mathrm{mg} / \mathrm{L}$. Setelah perlakuan klorin mengalami penurunan pada perlakuan kontrol $(\mathrm{K})$, L.minor $(\mathrm{L}), H$. verticillata $(\mathrm{H})$ dan kombinasi L1H1 namun tidak terjadi penurunan pada perlakuan L1H2 dan L2H1. Perlakuan L1H1 merupakan perlakuan dengan penurunan tertinggi yaitu $0,110 \mathrm{mg} / \mathrm{L}$ (Tabel. 5). Menurunnya klorin diduga disebabkan klorin diserap oleh $L$. minor dan $H$. verticillata untuk metabolisme. Klorin diserap tumbuhan untuk menstimulasi pemecahan molekul air pada proses fotosintesis (Lakitan, 2006). Peningkatan klorin pada perlakuan kombinasi L1H2 dan L2H1 menjadi 0,25 $\mathrm{mg} / \mathrm{L}$ (Tabel. 5) mengindikasikan klorin masih berada di atas baku mutu berdasarkan Peraturan Pemerintah Republik Indonesia Nomor 82 Tahun 2001 yaitu 0,03 mg/L.

Pengukuran klorin pada perlakuan kontrol (K) tanpa tumbuhan lebih besar dibanding perlakuan dengan tumbuhan yaitu $0,04 \mathrm{mg} / \mathrm{L}$ (Tabel. 5). Hal ini sejalan dengan pernyataan Budi (2006) menyatakan klorin dapat turun dengan cepat tanpa tumbuhan air. Hal ini disebabkan klorin akan bereaksi dengan sisa-sisa organik dari limbah cair dan akan membentuk senyawa halogen organik yang mudah menguap (volatile halogenated organics) sehingga klorin berkurang. Hasil pengukuran klorin paling tinggi yaitu 0,025 pada perlakuan $\mathrm{L} 1 \mathrm{H} 2$ dan $\mathrm{L} 2 \mathrm{H} 1$ (Tabel. 5).

Hasil penelitian menunjukkan adanya pengaruh air limbah laundry terhadap penurunan pertumbuhan $L$. minor dan $H$. verticillata pada semua perlakuan (Tabel. 6). Penurunan pertumbuhan diduga berkaitan dengan kemampuan tumbuhan air dalam menyerap unsur hara yang terkandung dalam limbah laundry. Menurut Kvesitadze et al. (2006), penurunan biomassa tumbuhan air yang digunakan untuk fitoremediasi berkaitan dengan kemampuan atau batas toleransi tumbuhan tersebut dalam menyerap unsur-unsur hara yang terkandung dalam air limbah.

\section{DAFTAR PUSTAKA}

Agussetyadevy, Imbar, Sumiyati, S \& Sutrisno, E 2013, 'Fitoremediasi Limbah yang Mengandung Timbal $(\mathrm{Pb})$ dan Kromium $(\mathrm{Cr})$ dengan Menggunakan Kangkung Air (Ipomea aquatic)', Jurnal Teknik Lingkungan vol. 2, hal. 1-9
Budi, SS, 2006, 'Penurunan Fosfat dengan Penambahan Kapur (Lime), Tawas dan Filtrasi Zeolit pada Limbah Cair (Studi Kasus RS Berthesda Yogyakarta)',Eprints.undip.ac.id/18012/Sudi _Setyo_Budi.pdf, diakses 25 Oktober 2017

Dewi, YS \& Masithoh, M, 2015, 'Efektifitas Teknik Biofiltrasi dengan Media Bio-ball Terhadap Penurunan Kadar Nitrogen Total', Jurnal Ilmiah, Fakultas Teknik LIMIT'S, vol. 9, no. 1, hal. 45-43

Endro, S, Sumiyati, S \& Nurdiansyah, 2010, 'Pengaruh Tanaman Rumput Bebek (Lemna minor) Terhadap Penurunan BOD dan COD Limbah Cair Domestik', Jurnal Presipitasi, Media Komunikasi dan Pengembangan Teknik Lingkungan vol. 7, no. 1, hal. 42-47

Hanafiah, KA, 2004, Rancangan Percobaan: Teori dan Aplikasi, Raja Grafindo, Jakarta

Hidayah, EN \& Aditia, W,2010, 'Potensi dan Pengaruh Tanaman Pada Pengolahan Air Limbah Domestik Dengan Sistem Constructed Wetland', Jurnal Ilmiah Teknik Lingkungan, vol. 2, no. 2, hal. 1-6

Kristanto, P, 2002, Ekologi Industri, Penerbit ANDI Yogyakarta dengan LPPM Universitas Kristen Petra Surabaya

Kvesitadze, G, Khatisashvili, G, Sadunishvili, T \& Ramsden JJ, 2006, Biochemical Mechanisms of Detoxification in Higher Plant, Springer Verlag Berlin, Germany

Lakitan, B, 2006. Pengantar Kesehatan Lingkungan, EGD, Jakarta

Muhajir, MS, 2013, 'Penurunan BOD dan COD Limbah Cair Industri Tahu Menggunakan Tanaman Cattail (Typha angustifolia) dengan Sistem Constructed Wetland', Universitas Tanjungpura, Pontianak

Nasrullah, S, Rita, H \& Ulli, K, 2015, 'Pengolahan Limbah Karet dengan Fitoremediasi Menggunakan Tanaman Typha angustifolia', Jurnal Teknik Lingkungan, Universitas Tanjungpura, Pontianak

Oktavia, Rusyani \& Rini, 2013, 'Potensi Tumbuhan Genjer, Kangkung dan Eceng Gondok Sebagai Agen Fitoremediasi pada Air Limbah Laundry yang Mengandung Fosfat', Skripsi, Universitas Negeri Gorontalo, Gorontalo

Peraturan Pemerintah Republik Indonesia Nomor 82 Tahun 2001 Tentang Pengelolaan Kualitas Air dan Pengendalian Pencemaran Air

Reddy, KR, \& De Busk, WF, 1985, 'Nutrient Removal Potential of Selected Aquatic Macrophytes', jurnal environmental, vol. 1, hal. 459-462 
Savitri, 2007, 'Pengolahan Limbah Deterjen Sintetik dengan Trickling Filter' [Makalah Penelitian] http://eprints.undip.ac.id, diakses 29 Agustus 2017

Sudiro \& Agnes, TA, 2013, 'Kajian Efektifitas Tanaman Air Lemna minor dan Hydrilla verticillata dalam Mereduksi BOD dan COD sebagai Upaya Perbaikan Kualitas Limbah Cair Industri Tahu', Jurnal Spectra, Jurusan Teknik Lingkungan Institut Teknologi Nasional, Malang

Sumiyati, S, Dwi, SH \& Widya, H, 2009, 'Pemanfaatan Hydrilla verticillata untuk Menurunkan Logam Tembaga $(\mathrm{Cu})$ dalam Limbah Elektroplating Studi Kasus : Industri Kerajinan Perak Kelurahan Citran, Kotagede', Jurnal Presipitasi: Media Komunikasi dan Pengembangan Teknik Lingkungan vol.6, no. 2, hal. 3-26
Tati, R, 2017, 'Penurunan Kadar Total Suspended Solid (TSS) Air Limbah Pabrik Tahu dengan Metode Fitoremediasi Menggunakan Tanaman Hydrilla verticillata', Jurusan Kesehatan Lingkungan, Politeknik Kesehatan KEMENKES, Bandung

Utami \& Rina, H, 2018, 'The Application of Phytoremediation Lemna perpusilla to Increase the Production Performance of Nile Tilapia Oreochromis niloticus in a recirculation system', Jurnal Akuakultur Indonesia vol. 17, no. 1, hal. 34-42

Wardhana \& Wisnu, A, 2013, Dampak Pencemaran Lingkungan (Edisi Revisi), Penerbit Andi, Yogyakarta 